\title{
Bambusa tulda Roxb. in Manipur State, India: Exploring the Local Values and Commercial Implications
}

\author{
Potsangbam Kumar SINGH ${ }^{1)}$, Sorokhaibam Padma DEVI ${ }^{1)}$, Keisham Kabita \\ DEVI' ${ }^{1)}$, Deshworjit Singh NINGOMBAM ${ }^{1)}$, Pinokiyo ATHOKPAM ${ }^{2)}$ \\ 1) Manipur University, Ethnobotany and Plant Physiology Lab., Department of Life \\ Sciences,Canchipur-795003,Manipur;potksingh@indiatimes.com \\ 2) Nambol L. Sanoi College, Department of Botany, Nambol, Bishnupur, Manipur;pinkiathokpam@gmail.com
}

\begin{abstract}
Tropical moist climate in Manipur supports rich and luxuriant growth of Bambusa tulda Roxb. locally known as Saneibi, which is endemic to northeastern region and West Bengal of India. It represents one of the most costly species of bamboo in Manipur, its price ranging from Rs. 70-150/-per mature bamboo culm. The meitei Manipuris have a rich traditional knowledge for utilization of this particular bamboo species. In fact, it has got multipurpose use covering several aspects from religious to industrial. Because of its strength and durability it is of great demand on the market. Its young shoots (ushoi) and the fermented young shoots (soibum) represent a significant vegetable for local people. Ushoi costs Rs.10-50/- per piece while soibum cost Rs. 30-50/- per kg. Local medicine man use this for healing properties. It forms a good raw material for various handicraft works, house building, paper industries, fencing, and several other useful equipments for day to day life. This bamboo species could yield more than 15 very commonly used and highly marketable articles with prices ranging from Rs.10/-to Rs 300/-per piece. Therefore, the development of small scale industries with highly skilled handicraftsmen can be profitable. Plantation of this bamboo species on farmland, borders of home garden, foothills, riversides, sides of ponds will prove to be a good business as well as a proper help in the conservation and sustainable management of this endemic species. Traditional mode of propagation is done successfully through off-set planting method. This paper presents a detailed study on this particular bamboo species regarding taxonomy, status of distribution, density, regeneration capacity, traditional uses, methods of processing and its commercial implications highlighting the eco-friendly nature of bamboo plantation and bamboo products.
\end{abstract}

Keywords: Bamboo-hut, suspension-bridge, pillars, decorative items, fishing-equipments, processing

\section{Introduction}

Bamboos, the green gold, formed poor man's timber providing all the necessary materials to replace timber products. Out of 126 species of bamboos reported from India over 40 species are found in Manipur and about 15 species of Bambusa native of Manipur (Chauhan, 1999). Species of bamboos are distributed abundantly in Manipur and most of these are economically important to the people of the state. The role of bamboos in everyday life is immense and commendable. Bamboos help to meet the basic necessities of life i.e. food, fuel, clothing and shelter and also serve as a raw material for many industries such as paper (Negi, 1996). A single species of bamboo has multipurpose use. Several works have been published on Bamboos-seed germination and propagation of bamboos (Banik, 1987; 1988); bamboo plantation techniques (Prasad, 1987); industrial use as a source of raw material for paper (Adamson, 1960), board (Guha, 1961) and handicraft (Chakraborty, 1988); bamboo as a source of nutrition (Bhargava et al., 1996); taxonomy of bamboos (Bahadev, 1979; Barooah and Borthakur, 2001; Bennet \&
Gaur, 1990; Brandis, 1899; Naithani, 1990; Naithani et al., 2008; Negi and Naithani, 1994; Shukla, 1996; Tewari, 1992); Bamboo harvesting methods (Kulkarni, 1971). However, selective species and specific studies with their uses and commercial implications are very few. In this respect, authors feel the need of documentation of all the details of economically significant species of bamboos, so that this can give the basic information for commercialization. Keeping in mind the significance of Bambusa tulda locally known as Saneibi to local people of Manipur (Meiteis), it was selected for the present study. The study will help in the proper assessment of the particular species as well as for the selection of suitable species for conservation, management, sustainable utilization and effective commercialization of the bamboos.

\section{Materials and methods}

\section{Survey and collection}

Several localities in different districts of the State were surveyed for the availability of Bambusa tulda. It was recorded as growing prominently in Andro, Bamon Kampu, 
36

Baruni foothills, Top, Jiribam riversides in Imphal East, Lamdeng, Lamshang, Konthoujam, Leimaram, Khumbong, Malom, Sekmai, Pheidinga, Khonghampat, Langol area, in Imphal West district, Phayeng, Nambol, Thanga, Kumbi-Keirenphabi in Bishnupur district, Foothills of Churachandpur district, Lilong, Thoubal, Kakching, Pallel in Thoubal district. Flowers were collected during the months of April and May, 2009. All the specimens collected were deposited in the herbarium Department of Life sciences, Manipur University, Canchipur, Manipur. To record the density of the species a quadrate of $1 \mathrm{~m}^{2}$ is laid randomly to some selected sites. All the traditional uses were recorded through formal and informal interviews with local persons from 68 localities in 24 villages with the permission from head man of the villages. Market prices were recorded mainly from the city markets at Imphal, accordingly range of prices of articles have been noted seasonally. Seasonal demands of each articles on the market is also analyzed.

\section{Identification}

The specimens were collected on the basis of local name and identified for its scientific name consulting literature and herbarium at Botanical Survey of India, Eastern Circle, Shillong, Meghalaya, India.

\section{Results and discussion}

\section{Bambusa tulda Roxb.}

A moderate sized, densely tufted, sympodial bamboo species. Culms green, glabrous when young, without spines, of 8-20 m high; $5-10 \mathrm{~cm}$ in diameter, erect, walls $7-15 \mathrm{~mm}$ thick, branching starts at the upper nodes, branches several, gives a very bushy look, horizontal growth; nodes not swollen, lower ones fibrous rooted; internodes $30-60 \mathrm{~cm}$; culm sheaths $15-25 \mathrm{~cm}$ long and $18-30 \mathrm{~cm}$ broad, rounded or triangularly truncate at top, imperfect blade broadly triangular, hairy within, the base decurrent into rounded, large, long fringed auricles, or a wavy narrow-fringed band along the upper edge of the sheaths; auricles 2, unequal, at least one lateral or wavy, continuous with blade; ligule narrow, entire. Leaves linear-oblong or linear-lanceolate, $15-25 \mathrm{~cm}$ long and $2-4 \mathrm{~cm}$ broad, usually rounded at the base, ends into a $5 \mathrm{~mm}$ long hairy petiole, acuminate above in a subulate twisted point; inflorescence variable, large, sometimes an immense radical leafless panicle, sometimes a short leafy paniculate or spicate branch; branches spicata, bearing interrupted clusters of few (1-5) usually fertile long spikelets, supported by shining bracts of rachis smooth striate. Spikelets variable in length, $2.5-8 \mathrm{~cm}$ long sessile, glabrous, cylindrical and acute at first, afterwards divided, 7-12 flowered, often hirsute at the top with 1-2 empty bracts at the base, followed by several glumes, lower 2-4 florets male or sterile, central floret hermaphrodite, lemmas smooth, shining, acuminate, membranous at the base, ca $2.5 \mathrm{~cm}$ long, palea slightly shorter or as long as the lemma, 2 keeled, ciliate on the keels; lodicules 3, of which 2 obtuse; the third lanceolate; stamens 6 , rarely 3 by abortion, exerted, light purple; ovary stipitate, obovate, hairy on the top; stigmas 3; fruits oblong or obovate, hirsute on the top.

This species somewhat resembles of B. vulgaris Schard. which could however be easily differentiated since the latter species has got sub equal auricles. $B$. tulda is also similar to B. nutans Wall. ex Munro with the auricles of the culm sheath are never on lateral but both the auricles of the culm sheath are on the top of the sheath. It is sometimes misidentified as Bamboosa bamboos (L.) Voss. which has yellow anthers and recurved spines at the lower branches of culms.

\section{Flowering and Fruiting: March-July}

Chemistry: Chemical analysis of Bamboo shoot of this species was carried out by Singh \& Singh (1994). This species contains $2.76 \%$ protein, $0.18 \%$ free amino acids, $0.34 \%$ starch, $1.67 \%$ soluble sugar, $1.09 \%$ reducing sugar, $0.58 \%$ non reducing sugar, $0.01 \%$ lactic acid, $0.01 \%$ volatile acid, $0.03 \%$ diacetyl, $0.04 \%$ Citric acid, $0.61 \%$ free Phosphate, $0.03 \%$ Phenolic compound, $0.01 \%$ Ethanol. These results are expressed in terms of percentages of the wet mashes.

Specimens examined: Manipur, Imphal West district, Lamshang, alt. ca 750 m, Singh \& Kabita, 001703; Imphal East district, Kongpal, alt. ca700 m, Pinokiyo \& Padmabati, 001704 .

\section{Distribution}

This species is endemic to Northeastern region and West Bangal. It grows suitably in moist tropical climate and extends its altitudinal distribution up to $1500 \mathrm{~m}$ above sea level and sometimes reaching up to temperate regions. In Manipur the species is distributed in wild as well as in cultivated forms. It is a fast growing species and is usually found in the periphery of gardens, sides of pond, landscape of fields and foothills. There is no vast plantation or vast natural occurrence like Malacona baccifera (Roxb.) Kurz.. However, interestingly the species is usually planted traditionally in home gardens of most of the houses in Manipur as wapal i.e. a patch of bamboo planted around the house to protect from wind, storm, animals, encroachments and for its use in ritual ceremony and household purposes. $\mathrm{Wa}$ pal is a way through which Bamboo species is conserved traditionally. Our survey on the population study of this particular bamboo species to some selected localities revealed that bamboos were found in patches of up to 1-3 $x$ 5-100 per $\mathrm{m}^{2}$ with an average density of 7 individuals per $\mathrm{m}^{2}$. Common sites of distribution are already mentioned above.

\section{Propagation}

This species prefers alluvial soil in good rainfall areas and fine textured soil in semi evergreen forests, in relatively low rainfall areas with subtropical to temperate cli- 


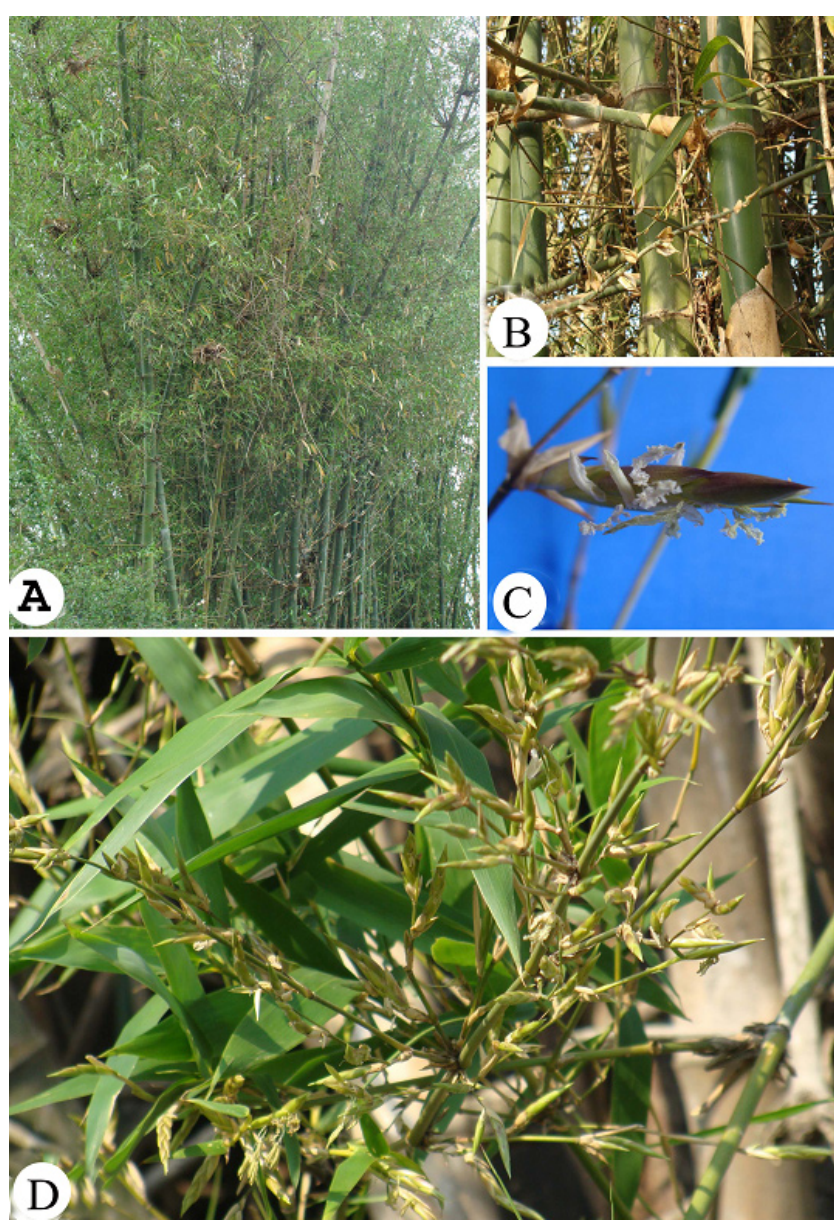

Fig. 1. Bambusa tulda A. Habit; B. Branches, node and culm sheath; C. Flowers;D. Inflorescence

matic conditions. The traditional mode of propagation is very successfully practiced in the state. In this propagation method a 1-2 years old, healthy culm is selected. This culm along with rhizome and root system is carefully separated from its mother clump by cutting at its neck. It is again cut at above the $1^{\text {st }}$ internode towards the top. Cut top of the clump is covered with mixture of mud and cow dung to prevent drying up. This cover should be air tight and sprinkled with water frequently. This is an offset ready for plantation. A pit of $60 \times 60 \times 60 \mathrm{~cm}^{3}$ is dug and poured sufficient water. The offset thus prepared is planted in to this pit and covered with soil in such a way that no air space is left. Planting should be done during or just before rainy season. Other modern methods of propagation are already discussed in detail by Prasad (2008). Seeds can be used for large scale propagation. Though this species is monocarpic, it undergoes gregarious flowering. The seeds show 3 months viability, germination takes 9-30 days, 92\% viability under proper storage condition (Ahlawat et al., 2002).

\section{Traditional way of harvesting and processing}

It is always better to harvest fully matured bamboos which are at least 3-4 years old during dry season i.e.

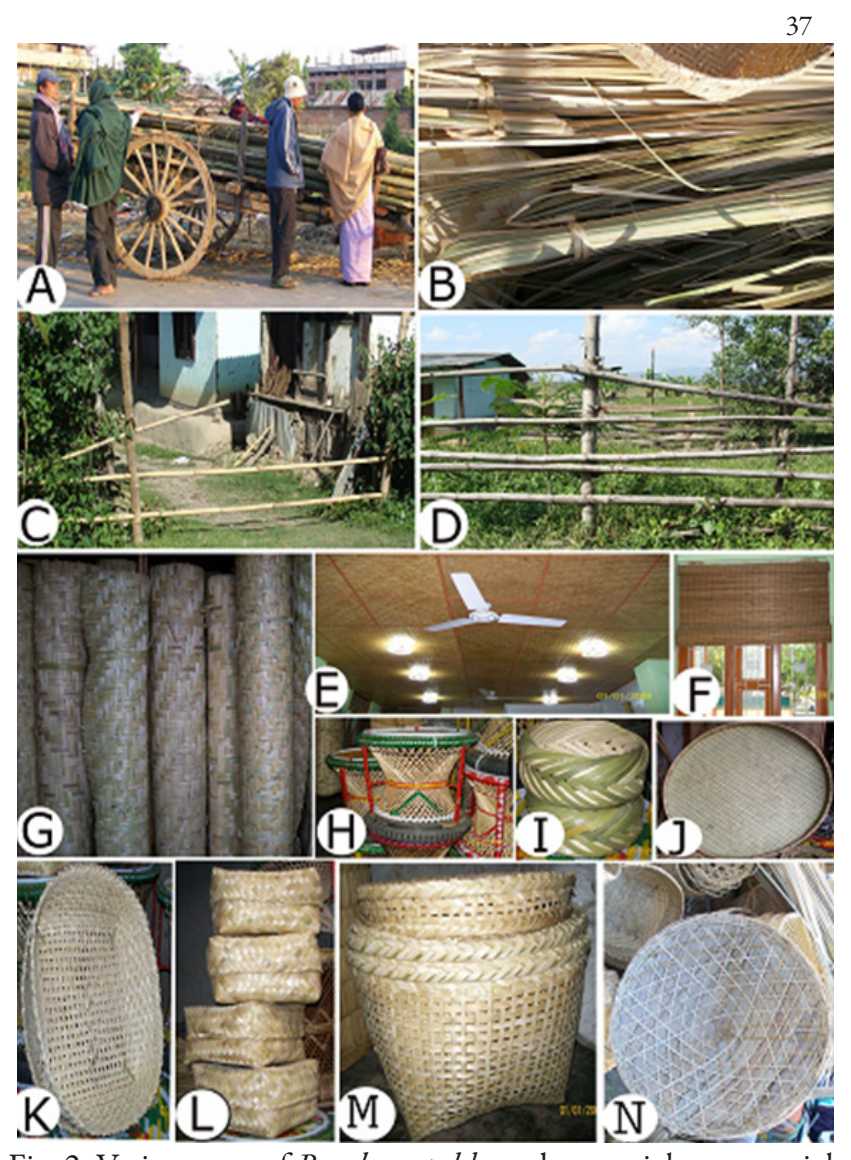

Fig. 2. Various uses of Bambusa tulda and potential commercial products: A. Bamboo culms at sell; B. Paya and Wachet sold as raw material; C. Konthong; D. Sambal; E.Ceiling made of bamboo; F. Bamboo shutter used as curtain; G. Faklong; H. Mora; I. Feija; J. Yangkok; K. Kharai; L. Ngarubak; M. Polang; N. Chakup

from the month of October to March when the habitat area is comparatively drier. Meities have rich traditional pretreatment knowledge to protect the culm from insect and fungal infections. The culm is kept deep inside water for 3-4 months. In case, if the culm is to be used for furniture some salt is added to the water. Bamboo culms are also treated with cow urine for about 10-15 days. After this, these culms are taken out and allowed to dry in the sun for another 10-20 days. Another traditional method of processing is - after harvesting the bamboo culm is kept for 10-15 at the very place of harvesting by removing the culm sheaths and leaves, branches, etc., then the culms are covered by bamboo leaves and culm sheaths for about 20 days. By doing this the culms become lustrous and free from fungal attack. Processing of bamboo is also done traditionally by putting the bamboo culm in pit full of cow dung for about 10-20 days. This makes the culms straighter and lustrous.

\section{Ethnobotanical uses}

Religious ceremony: This bamboo plays an eminent role as it is used to erect a pillar (Ukhong) or a post called jatra 
Tab. 1. Value added articles of $B$. tulda having commercial implications

\begin{tabular}{|c|c|c|c|c|c|c|}
\hline $\begin{array}{l}\text { Articles } \\
\text { in their } \\
\text { traditional } \\
\text { name }\end{array}$ & Raw material & Skill & Quantity & $\begin{array}{c}\text { Cost of raw } \\
\text { material } \\
\text { (Rs.) }\end{array}$ & $\begin{array}{l}\text { Market price } \\
\text { in rupees } \\
\text { (Rs.) }\end{array}$ & Demand \\
\hline Ukhong & Whole culm (mature) & B & One piece & $50 /--120 /-$ & $70-150 /-$ & High \\
\hline Wachet & -do- & B & $1-3$ bunches & - do- & $50-150 /-$ & High \\
\hline Ushoi & Fresh young shoot & B & -do- & - & $10-50 /-$ & $\begin{array}{l}\text { Seasonal very high } \\
\text { (May-August) }\end{array}$ \\
\hline Soibum & Young shoot & A & $1 \mathrm{~kg}$ & $10 /-$ & $30-40 /-$ & Very high \\
\hline Phiruk & Paya & A & 4-6 bunches & 60-90/- & $250-300 /-$ & Moderate \\
\hline Paya & $\begin{array}{l}\text { Longitudinal slices } \\
\text { of bamboo culm }\end{array}$ & B & 1 meter length culm & $10-15 /-$ & $20-30 /-$ & Moderate \\
\hline Polang & Paya & A & 1 bunch & $10-15 /-$ & $30-50 /-$ & High \\
\hline Phoura & Wachet & A & $1-2$ bunch & $50-100 /-$ & $200-300$ & Moderate \\
\hline Yangkok & Paya & A & $2-4$ bunch & $30-45 /-$ & 60-90/- & Moderate \\
\hline Kharai & -do- & A & $1-2$ bunch & $15-30 /-$ & $25-40 /-$ & Moderate \\
\hline Sumjit & -do- & B & $1 / 2$ bunch & $7 /-$ & 10/- & High \\
\hline Mora & Wachet & A & $1 / 2$ bunch & $25 /-$ & $100-150 /-$ & High \\
\hline Ngarubak & Paya & A & $1 / 2-1$ bunch & $7-15 /-$ & $20-30 /-$ & High \\
\hline Long-oop & Wachet & A & $1 \frac{1 / 2-2}{}$ bunches & $35-50 /-$ & $160-200 /-$ & Moderate \\
\hline Taijeb & Wachet & A & $1 / 2-1$ bunch & $7-15 /-$ & $35-50 /-$ & $\begin{array}{c}\text { Seasonal } \\
\text { very high (July to September) }\end{array}$ \\
\hline $\mathrm{Lu}$ & Wachet & A & $1 / 2-1$ bunch & $7-15 /-$ & $35-50 /-$ & $\begin{array}{c}\text { Seasonal } \\
\text { very (high July to September) }\end{array}$ \\
\hline
\end{tabular}

A=high skill required, $\mathrm{B}=$ less skill required

while constructing a mandop (tent house) for the inauguration of every religious ceremony whether it is a wedding or a death ceremony.

Medicine: The crush bamboo shoot juice is applied to the injury of nails due to iron sword or arrows. The boiled decoction of the fermented shoot is prescribed for ring worm, tumours and meningitis. The fruits are belief to enhance fertility.

House building: Whole bamboo culm of suitable length and size are used as pillar (Ukhong) in bamboo huts (Shang) and houses (Shanglen). The $1^{\text {st }}$ pillar of the house, traditionally called Yatra is usually the culm of this species.

Fencing: Suitably cut bamboo culms are used as pillars, while split culms are used as horizontal guards which are again fastened to the pillars with the help paya (Tab. 1). The whole fencing system is known as Sambal (Tab. 1).

Bridges: Good quality culms and split culms are used for suspension bridges built across big rivers joining hills, mountains with villages enabling the villagers the collection of forest products for their livelihood. Thongra is prepared using 1.5-2.4 m long, of 3-5 numbers of culms. The culms are placed together forming a platform over water being supported by other 4 stands and two horizontal supports. This platform so called Thongra is built to facilitate fetching water, bathing, washing clothes, cleaning utensils, etc. from pond and rivers.
Guard walls: Culms of this species are strong and used as guard walls for stair-case for houses, gates and boundaries of houses, to prevent erosion of riverbanks.

Gate: Konthong (Fig. 2C), the traditional gate for houses, farm houses, etc. is constructed using 6-10 big sized culms.

Baskets and containers: Polang (Fig. 2M), thumok, Phingairuk, Kharai (Fig. 2K), Yangkok (Fig 2J), Phiruk, Ngarubak (Fig. 2L), Phoura, etc. all are prepared from Paya.

Decorative items: Artificial flowers, wall hangings, Phiruks, flower vase, pen slits, trays, etc.

Vegetable: The fresh bamboo shoot known as ushoi and the fermented bamboo shoot commonly called as soibum are of high delicacy so, they are of much demand. Ushoi Uti (curry prepared from Ushoi and pea) is a special item of curry in every celebration.

Stuffing material: The leaf is dried and used as stuffing material for mattress.

Fuel: The whole bamboo is used as firewood after it is dried mainly the leaves, culm sheaths, and the dried culms.

Fishing equipments: Taijeb (Fig. 3B) and long-oop (Fig. 3A), lu (Fig. 3C), etc. are fishing implements commonly used by the people of Manipur ; the instruments are prepared from the split culms of this bamboo.

Brooms: Urong-Sumjit is made of paya.

Stools: Mora is made from by splitting culms. 


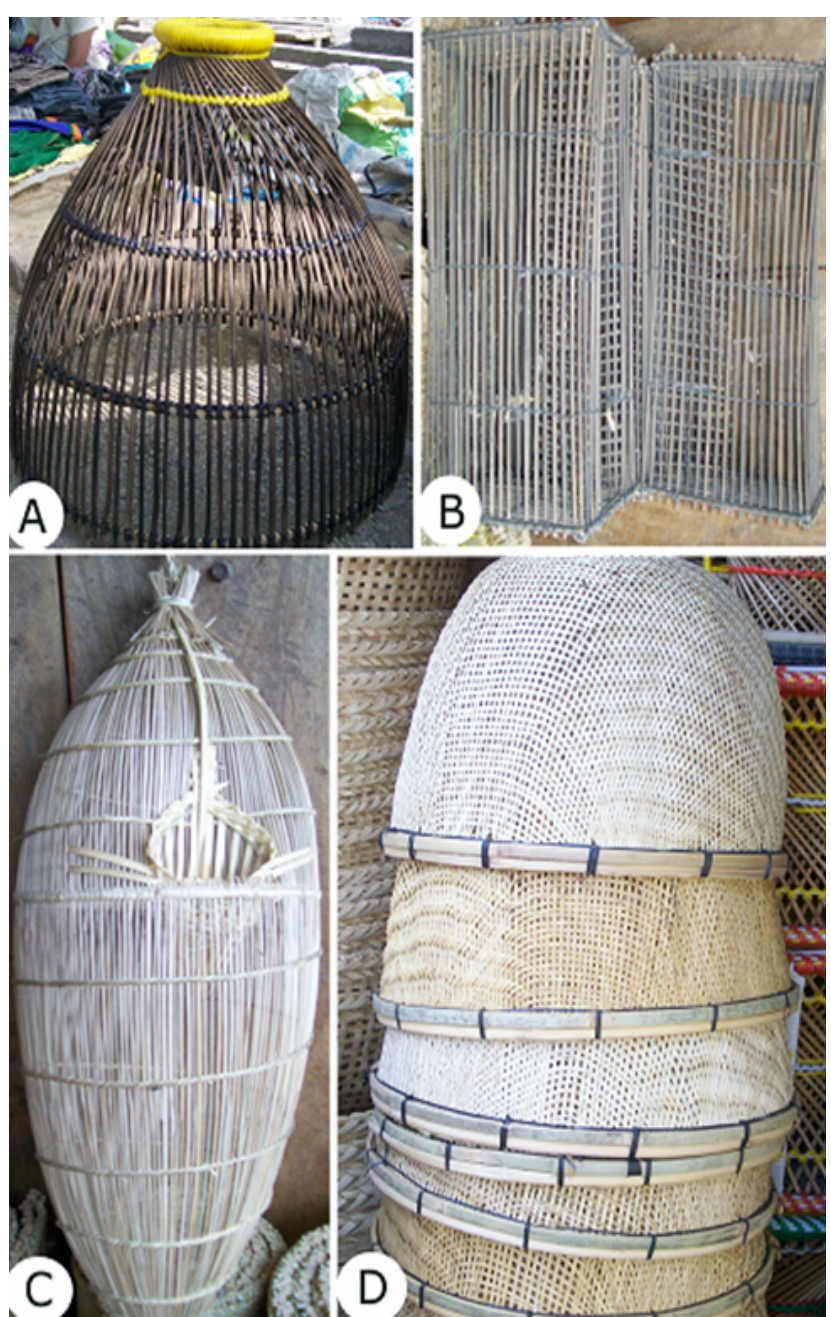

Fig.3. Fishing equipments: A. Long-oop; B. Taijeb; C. Lu; D. Long

\section{Implications for commercialization}

There is a significant scope for commercialization of this bamboo species since it can be an efficient cost effective raw material (Tab. 1) for small scale handicraft industries. This species is one of the high yielding bamboos suggested for large scale plantation (Prasad, 2008). Durability, fast growing (could be used within 2-3 years after plantation), readily available, easy handling, requiring only manual labour again adds up to its efficiency for commercialization. Even 18 months old plants can yield pulp for paper. This species is easily multiplied, matures within short duration, needs little care, and less affected by diseases. One mature bamboo produces 1-3 young shoot(s) per year which is a good rate of natural multiplication. From Tab. 1 it can be observed that the bamboo species could be sold as a raw material or in the form of several articles of daily use in Manipur. Here, manual labour is a must and well trained skilled handicraftsmen are required for setting up small scale industries. The more is the handwork, the more is the price of the article. Jobless local people either male or female could help to this purpose. Availability of market is not a problem since the products are used essentially in daily life of Meities of the state.

\section{Conclusions}

\section{Conservation, management and sustainability}

Nowadays, the demand of this bamboo on the local market is very high and could not be met with the present scale of production which largely depends on plantation by local people in their plots as boundary plants. Wapal is a way through which bamboos are planted, conserved and managed sustainably by the local people. However, due to over population, development of cities, urbanization and construction of houses closely this culture is being abandoned slowly in the city areas of the state. In such a situation, an increase in plantation of this particular species is highly needed. These could be planted in and around the farmlands as a purpose for bio-fencing, near ponds and river banks for soil binding and to prevent soil erosion. There are certain non degradable plastic articles (plastic ropes, baskets, brooms, stools, decorative items, etc.) which can be replaced easily by biofriendly-degradable products of this bamboo species. From the economic point of view, large scale production is highly imperative for their better commercialization. In this connection, introduction of a well managed programme for the plantation and conservation of this particular species is highly imperative for their sustainable utilization. Further, highly skilled local people could be utilized for establishing small scale industries as market is already available. Singh (2008) mentioned that almost 5,000 crores worth of raw bamboo is available in North East India and even 2 fold value addition can create an industry worth of Rs 10,000 crores. Value added articles shown in Tab. 1 could be the basis of industrialization. This, if, implemented, can also help in preventing fast depleting timber resources of the state. Therefore, Bambusa tulda proves to be an economically and ecologically significant bamboo species in the state which deserves proper attention for commercialization and conservation.

\section{Acknowledgements}

The authors are thankful to the Head, Department of Life Sciences, Manipur University for facilities and to the Joint Director, Botanical Survey of India, Eastern Circle, Shillong for allowing herbarium consultation. One of the authors (SP Devi) is grateful to Department of Science and Technology (DST), New Delhi for women Scientist fellowship. We are also thankful to local men and village heads of Manipur for their co-operation.

\section{References}

Adamson, G. A. (1960). Bamboo, long known as source of paper pulp, awaits developments in handling, chipping. Paper and Pulp Industries 2(5):23-24. 
40

Ahlawat, S. P., K. Haridasan and S. N. Hedge (2002). Field Manual for Propagation of bamboo in North East India. State Forest Research Institute, Itanagar, Arunachal Praedesh, India.

Bahadev, K. N. (1979).Taxonomy of bamboos. Indian Journal of Forestry 2(3):222-241.

Banik, R. L. (1987). Seed germination of some bamboo species. Indian Forester 113(8):578-586.

Banik, R. L. (1988). Investigation on culm production and clump expansion behavior of five bamboo species of Bangladesh. Indian Forester 114(9):576-583.

Barooah, C. and S. K. Borthakur (2001). Four new species of Bambusa Schreber from Assam, India. Indian Journal of Forestry 24(4):503-509.

Bennet, S. S. R. and R. C. Gaur (1990). Thirty seven bamboos grown in India. Forest Research Institute, Dehradun, India.

Bhargava, A., V. Kumbhare, A. Srivastava and A. Sahai (1996). Bamboo parts and seeds for additional source of nutrition. International Journal of Food Science and Technology 33:145-146.

Brandis, D. (1899). Biological Notes on Indian Bamboos. Indian Forester 25(1):1-25.

Chakraborty, D. (1988). Utilization of bamboo as raw material in the handicraft industries Tripura. Indian Forester 114(10):635-636.

Chauhan, A. S. (1999). Manipur, p. 1149-1153. In: Floristic Diversity vol. 3. Botanical Survey of India, Kolkata, India.

Guha, S. R. D. (1961). Bamboo as raw material for paper and board making. Indian Buyer 1(2):14-15.

Kulkarni, M. M. (1971). Practical implication of silvicultureal felling rules of Bamboo. The Andhra Pradesh Paper Mills Forest News letter.

Naithani, H. B. (1990). Two new combinations of bamboos (R.N.). Indian Forester 116(12): 990-991.

Naithani, H. B., S. S. Garbyal and J. P. Allappatt (2008). Flowering of Bambusa vulguris in Andaman \& Nicobar Islands. Indian Forester 134(9):1264-1268.

Negi, S. S. and H. B. Naithani (1994). A handbook of Indian bamboos. Dehradun, India.

Negi, S. S. (1996). Bamboos and Canes. Bishen Singh and Mahendra Pal Singh, Dehradun-248001, India.

Prasad, P. N. (2008). Propagation of Bamboo in Manipur. Indian Forester 134(3):325-332.

Prasad, R. (1987). Bamboo plantation: Standardization of techniques for raising nursery stock plantations and their aftercare in Madhya Pradesh. Bulletin, State Forest Research Institute, Jabalpur, Madhya Pradesh, India.

Singh, G. S. and L. J. Singh (1994). The study on the biochemical changes during the fermentation of soibum. BIC-India Bulletin 4(1/2):1-5.

Singh, O. (2008). Bamboo for sustainable India, Indian Forester 134(9):1193-1198.

Shukla, U. (1996). Grasses of North-Eastern India. Scientific Publishers, Jodhpur, India.

Tewari, D. N. (1992). Monograph on Bamboo. International Book Distribution, Dehradun, India. 